\title{
3-Sulphocatechol 2,3-dioxygenase and other dioxygenases (EC 1.13.11.2 and EC 1.14.12.-) in the degradative pathways of 2- aminobenzenesulphonic, benzenesulphonic and 4-toluenesulphonic acids in Alcaligenes sp. strain 0-1
}

\author{
Frank Junker, Thomas Leisinger and Alasdair M. Cook†
}

Author for correspondence: Alasdair M. Cook. Tel: +497531 884247 . Fax: + 497531882966

Institute of Microbiology, Swiss Federal Institute of Technology, ETH-Zentrum, $\mathrm{CH}-8092$ Zürich, Switzerland

\begin{abstract}
Alcaligenes sp. strain 0-1 utilizes three sulphonated aromatic compounds as sole sources of carbon and energy for growth in minimal salts medium benzenesulphonate (BS), 4-toluenesulphonate (TS) and 2-

aminobenzenesulphonate (2AS). The degradative pathway(s) in 2AS-grown cells are initiated with membrane transport, NADH-dependent dioxygenation and meta ring cleavage. The specific activity of the NADH-dependent dioxygenation(s) varied with the growth phase and was maximal near the end of exponential growth for each growth substrate. Cells were harvested at this point from BS-, TS- and 2AS-salts medium. Cells grown with each sulphonated substrate could oxygenate all three compounds, but only 2AS-grown cells consumed $2 \mathrm{~mol} \mathrm{O}_{2}$ per mol 2 AS or BS or TS. BS- and TS-grown cells consumed $2 \mathrm{~mol} \mathrm{O}_{2}$ per mol BS or TS but failed to oxygenate the product of oxygenation of 2AS, 3-sulphocatechol (3SC). These observations were repeated with cell extracts and we concluded that there were two sets of desulphonative pathways in the organism, one for 2AS and one for BS and TS. We confirmed this hypothesis by separating the degradative enzymes from 2AS-, BS- or TSgrown cells. A 2 AS dioxygenase system and a 35C-2,3-dioxygenase (35C230) were detected in 2AS-grown cells only. In both BS- and TS-grown cells a dioxygenase system for BS and TS was observed as well as a principal catechol 2,3-dioxygenase (C230-III), neither of which was present in 2AS-grown cells. The $35 \mathrm{C} 230$ was purified to near homogeneity, found to be monomeric $\left(M_{r}\right.$ 42000), and to catalyse 2,3-dioxygenation to a product that decayed spontaneously to sulphite and 2-hydroxymuconate. The 2AS dioxygenase system could cause not only deamination of $2 A S$ but also desulphonation of BS and TS. The BS dioxygenase could desulphonate BS and apparently either desulphonate or deaminate 2AS. Strain 0-1 thus seems to contain two putative, independently regulated operons involving oxygenation and spontaneous desulphonation(s). One operon encodes at least the 2AS dioxygenase system and $35 \mathrm{C} 230$ whereas the other encodes at least the BS/TS dioxygenase system and C230-III.
\end{abstract}

\footnotetext{
Keywords: Alcaligenes sp. strain O-1, desulphonation, multi-component dioxygenases, meta ring cleavage, convergent degradative pathways
}

\footnotetext{
† Present address: Faculty of Biology, University of Konstanz, D-78434 Konstanz, Germany.

Abbreviations: 2AS, 2-aminobenzenesulphonate; 2ASDOS, 2AS dioxygenase system; BS, benzenesulphonate; BSDOS, BS dioxygenase system; C230, catechol 2,3-dioxygenase; 3SC, 3-sulphocatechol; 3SC230, 3SC 2,3dioxygenase; TS, $p$-toluenesulphonate; TSDOS, TS dioxygenase system.
}

\section{INTRODUCTION}

Four mechanisms of desulphonation of aromatic compounds have been elucidated, all of which involve oxygenation directly or indirectly (Cook \& Leisinger, 1991; Junker et al., 1994). Two mechanisms involve 


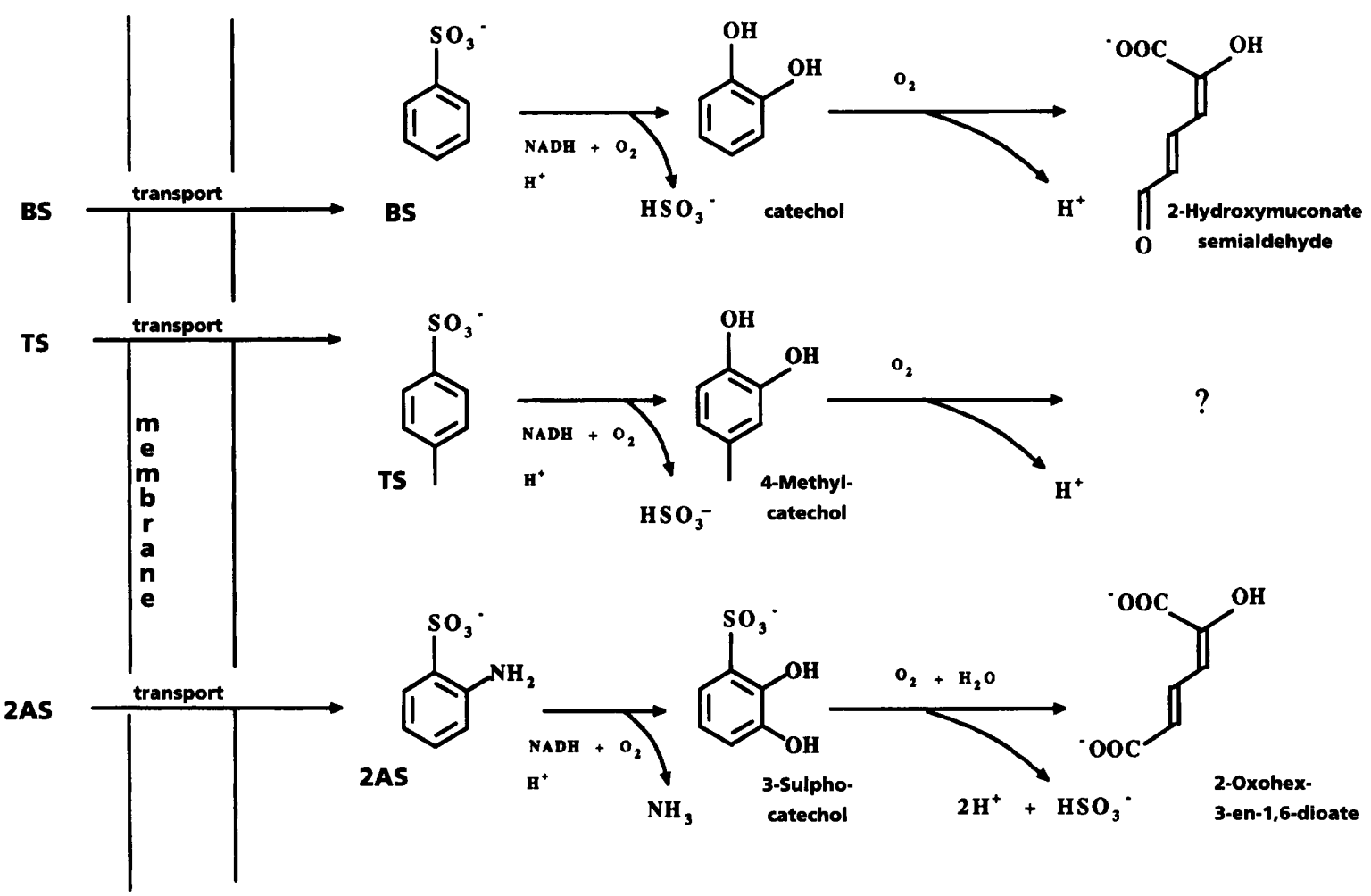

Fig. 1. Initial steps in the degradative pathway(s) for BS, TS and 2AS in 2AS-grown cells of Alcaligenes sp. strain O-1. All the illustrated reactions have been observed (Thurnheer et al., 1990; Junker et al., 1994). No structure for the ringcleavage product of 4-methylcatechol is shown, because we do not know whether 2,3- or 1,6-cleavage occurs. The presence of an arrow, e.g. 'transport', need not mean that a specific enzyme is present purely for that reaction.

desulphonation prior to ring cleavage; the catalyst has been purified in one case as a multi-component, NADHlinked dioxygenase system (EC 1.14.12.8; Locher et al., 1991), whereas the other reaction, a monooxygenation, has been observed in whole cells only (Zürrer et al., 1987). A representative catalyst of the third mechanism, which catalyses hydrolytic desulphonation subsequent to ring cleavage, has been purified (Feigel \& Knackmuss, 1993). The fourth mechanism, desulphonation associated with meta ring cleavage in Alcaligenes sp. strain O-1 (Junker $e t$ al., 1994), is examined in this paper.

Strain O-1 is known to utilize three sulphonated aromatic compounds as sole sources of carbon and energy for growth, orthanilate (2-aminobenzenesulphonate, 2AS), benzenesulphonate (BS) and 4-toluenesulphonate (TS) (Thurnheer et al., 1986). The degradative pathways for $\mathrm{BS}$, TS and 2AS in cells grown in 2AS-salts medium have been elucidated and found to consist of transport, NADHdependent dioxygenation and meta ring cleavage (Fig. 1) (Thurnheer et al., 1990; Junker $e t$ al., 1994; cf. Locher $e t$ al., 1993). Given the different mechanisms of desulphonation in Fig. 1, associated with either the NADHdependent dioxygenase (BS and TS) or with the meta ring cleavage (2AS), it is unclear how many sets of enzymes are involved in the three pathways. One of those sets, however, that for the degradation of $2 \mathrm{AS}$, is plasmidencoded (Jahnke et al., 1990).
Oxygenases are enzymes which introduce one or two atoms of oxygen from molecular oxygen into a substrate which is usually organic. These enzymes are found in some ten subclasses defined by the Enzyme Commission (e.g. Webb, 1992). Of those subclasses, two types of dioxygenases are relevant to this paper, (i) the multicomponent enzyme systems (EC 1.14.12.-) which typically initiate metabolic attack on inactive aromatic rings (Batie et al., 1992; Correll et al., 1992; Harayama et al., 1992; Mason \& Cammack, 1992), and (ii) the somewhat simpler dioxygenases (EC 1.13.11.-) involved in ringcleavage reactions (e.g. Lipscomb et al., 1992). The enzymes of EC 1.14.12. - can be further subdivided, but they all involve an electron transport chain of varying complexity which transfers electrons from NADH via a flavine and one or more [2Fe-2S] centres to the Rieske $[2 \mathrm{Fe}-2 \mathrm{~S}]$ centre on the oxygenase and then presumably to the mononuclear iron site where oxygen is activated prior to its attack on the named (non-reactive aromatic) substrate. By this means the aromatic substrate is activated and made available to less complex enzymes. The activation can lead to the spontaneous elimination of stable substituents (e.g. sulphono, halo, nitro, amino and ether functions) by generating unstable intermediates (a ring carbon carrying a hydroxyl group and a heteroatom) which lead to spontaneous loss of an anion (e.g. the good leaving groups sulphite, halide, nitrite, ammonia and phenolate/alkoxylate; Engesser et al., 1989; Junker et al., 
1994). Some of these enzymes can eliminate several anions (cited in Junker et al., 1994), others are highly specific (e.g. Locher $e t$ al., 1991). The dioxygenases of EC 1.13.11.2 are also somewhat heterogeneous (Harayama et al., 1992; Happe et al., 1993) but they are 'simple' in that only one type of subunit is involved. The activation of oxygen is at an iron centre, but no external reductant is needed. The reaction of catechol 2,3-dioxygenase opens the aromatic ring to yield a linear chain (e.g. Bayly \& Barbour, 1984; Whitman et al., 1991; Junker et al., 1994).

We initially anticipated there to be several multi-component desulphonative dioxygenases in strain O-1, because of the different patterns of apparent specific activities against a range of substrates observed in cell-free extracts from cells grown with the different arylsulphonates (Thurnheer et al., 1986). The problems involved in quantifying multi-component dioxygenases became apparent to us only later (Geary et al., 1990; Thurnheer et al., 1990; Locher et al., 1991; Bünz \& Cook, 1993), when we realised that either constant protein concentrations had to be used in assays, or that additions of otherwise limiting components were required. This uncertainty in the measurement of activity leads to uncertainty in the attribution of activity to a putative enzyme. So we presumed that our initial data on rates in crude extracts (Thurnheer et al., 1986) were suspect, because they were obtained at various protein concentrations; correspondingly the hypothesis on the number of oxygenases was suspect. The realization that different desulphonative mechanisms (Thurnheer et al., 1990; Junker et al., 1994) are present (Fig. 1) brought us back to the hypothesis of multiple sets of enzymes.

We have now shown that Alcaligenes sp. strain O-1 has two sets of specifically induced, desulphonative pathways, and that the substrate ranges of the enzymes in these two pathways in part overlap.

\section{METHODS}

Materials. The preparation of 3SC (Junker et al., 1994), the sources of chemicals (Junker et al., 1994; Thurnheer et al., 1986, 1990), as well as the commercial columns for enzyme separation and the molecular mass markers (Locher et al., 1991) are described elsewhere.

Analytical methods. Spectrophotometric and optical density measurements (Thurnheer et al., 1986; one OD unit at $500 \mathrm{~nm}$ represented $160 \mathrm{mg}$ protein $\mathrm{l}^{-1}$ ), reversed phase HPLC (Grossenbacher et al., 1986; Locher et al., 1989) and oxygen uptake measurements (Zamanian \& Mason, 1987) were done with apparatus described previously. Protein from whole cells was measured in a Lowry-type assay (Kennedy \& Fewson, 1968); protein in crude extracts and purifications was measured by the method of Bradford (1976). SDS-PAGE was done as previously described (Laemmli, 1970; Locher et al., 1991). The $\mathrm{N}$-terminal amino acid sequence of a blotted protein was determined by automated Edman degradation (Locher et al., 1991).

The organism, its growth and the preparation of cell extracts. Alcaligenes sp. strain O-1 (DSM 6325; Thurnheer et al., 1986; Jahnke et al., 1990) was maintained, grown and harvested under optimal conditions for the multi-component dioxygenase, as described elsewhere (Junker et al., 1994) or as indicated in the Results section. Cell pellets were suspended in extraction buffer ( $50 \mathrm{mM}$ Tris/HCl, $\mathrm{pH} 7 \cdot 5$, containing $20 \%, \mathrm{v} / \mathrm{v}$ glycerol), brought to $1 \mathrm{mM}$ PMSF, disrupted in a French pressure cell and centrifuged to remove particulate material (Junker et al., 1994). The supernatant fluid, called crude extract, was used for some experiments. Otherwise, crude extract treated with streptomycin sulphate to remove nucleic acids (Junker et al., 1994) was used for enzyme purifications.

Enzyme assays. 2-Aminobenzenesulphonate 2,3-dioxygenase system (2ASDOS), benzenesulphonate 1,2-dioxygenase system (BSDOS) or toluene-4-sulphonate 3,4-dioxygenase system (TSDOS) in crude extract were routinely assayed at $30^{\circ} \mathrm{C}$ as the rate of 2AS-dependent (or BS-dependent or TS-dependent) oxygen uptake in $0.25 \mathrm{ml}$ reaction mixtures. These contained about $12 \mu \mathrm{mol}$ Tris $/ \mathrm{HCl}, \mathrm{pH} 7.5,0.5 \mathrm{mg}$ protein, $150 \mathrm{nmol}$ $\mathrm{NADH}$ and $750 \mathrm{nmol} O \mathrm{OS}$ (or BS or TS) with which the reaction was started. When stoichiometry was being examined, $20 \mathrm{nmol}$ portions of sulphonate were used. When components of these multi-component enzyme systems were being located in separated protein fractions, $80 \mu \mathrm{l}$ portions of different fractions were used, irrespective of the protein concentration. The location of the components could be deduced from their colour (cf. Mason \& Cammack, 1992), the reductase being yellow and the oxygenase red. The reaction of the reductase was confirmed by its reaction with dichlorophenol indophenol and with cytochrome $c$ (cf. Locher $e t$ al., 1991).

3-Sulphocatechol 2,3-dioxygenase (3SC23O) and catechol 2,3dioxygenase $(\mathrm{s})(\mathrm{C} 23 \mathrm{O})$ in crude extract were routinely assayed photometrically $(374 \mathrm{~nm})$ at room temperature as formation of 2-hydroxymuconate semialdehyde from catechol (cf. Bird \& Cain, 1974). Reaction mixtures $(0.5 \mathrm{ml})$ contained $23 \mu \mathrm{mol}$ Tris/ $\mathrm{HCl}, \mathrm{pH} 7 \cdot 5$, about $50 \mu \mathrm{g}$ protein, $10 \mathrm{nmol} \mathrm{FeSO}$ and $5 \mu \mathrm{mol}$ catechol with which the reaction was started. When fractions from protein separations were examined, no attempt was made to set the protein concentration in the assay. These assays could also be quantified as substrate-dependent oxygen uptake rates with (substituted) catechols. When stoichiometry was being examined, $20 \mathrm{nmol}$ portions of catechols (catechol, 4methylcatechol or 3SC) were used in determinations of oxygen uptake.

Representative experiments involving oxygen uptake were tested for substrate disappearance and product formation. The reaction mixture was brought to $\mathrm{pH} 2$ with $\mathrm{HCl}$ to precipitate protein, which was removed by centrifugation. The supernatant fluid was examined by HPLC.

Separation and purification of enzymes. The enzymes studied were all sensitive to oxygen, so all solutions were sparged with oxygen-free nitrogen or helium prior to use. Where appropriate, solutions were protected by a blanket of nitrogen. Preliminary experiments were done with streptomycin-treated extracts of 2 AS-grown cells. We were unable to use a precipitation with ammonium sulphate to treat the extract, because there was extreme loss of activity ( $>60 \%$ ) which was not regained on reconstituting the fractions. Further, this extract was a stable solution of proteins which was unaltered visually by freezing and thawing, but during (or immediately after) anion-exchange chromatography many proteins precipitated. We thus chose a robust and relatively inexpensive DEAE-Sepharose column for the first separative step.

Step 1. The DEAE column $(15 \times 2.6 \mathrm{~cm})$ at $4{ }^{\circ} \mathrm{C}$ was used in an 
identical manner with extracts obtained from 2AS-, BS- or TSgrown cells. The column was equilibrated with $50 \mathrm{mM}$ Tris/ $\mathrm{HCl}$ buffer, $\mathrm{pH} 7 \cdot 5$, containing $0.1 \mathrm{mM} \mathrm{DTT}$ (buffer $\mathrm{A}$ ) at $2.5 \mathrm{ml} \mathrm{min}^{-1}$ and extract (400 $\mathrm{mg}$ protein) was applied to the column; $8 \mathrm{ml}$ samples were collected. Buffer $A$ was pumped for about 30 min when a linear gradient to $60 \%$ buffer $B(1 \mathrm{M}$ Tris/ $\mathrm{HCl}$, pH $7 \cdot 5$ containing $0 \cdot 1 \mathrm{mM} \mathrm{DTT})$ over $3 \mathrm{~h}$ was started.

Separated fractions from BS-grown cells were tested for BSDOS and $\mathrm{C} 23 \mathrm{O}$, fractions from TS-grown cells for TSDOS and $\mathrm{C} 23 \mathrm{O}$, and fractions from $2 \mathrm{AS}$-grown cells for $2 \mathrm{ASDOS}, \mathrm{C} 23 \mathrm{O}$ and $3 \mathrm{SC} 23 \mathrm{O}$. Attempts to concentrate proteins by membrane filtration led to extensive loss of activity, so active fractions were routinely desalted with a Sephadex $\mathrm{G}-25$ column equilibrated with buffer $\mathrm{C}\left(50 \mathrm{mM}\right.$ Tris $/ \mathrm{H}_{2} \mathrm{SO}_{4}, \quad \mathrm{pH} 7.5$ containing $0.1 \mathrm{mM} \mathrm{DTT}$ ) and used immediately. Occasionally, pooled fractions maintained on ice were brought to $80 \%$ saturation with $\left(\mathrm{NH}_{4}\right)_{2} \mathrm{SO}_{4}$ to precipitate proteins which were collected by centrifugation, taken up in a small volume of buffer $C$ and desalted.

Step 2. A pre-packed anion exchanger column (Mono Q; $10 \times 100 \mathrm{~mm}$ ) was routinely equilibrated at room temperature with buffer $C$ at $0.7 \mathrm{ml} \mathrm{min}^{-1}$ and $1 \mathrm{ml}$ samples were collected. A sample of 2 to $5 \mathrm{ml}$ of $(3 \mathrm{~S}) \mathrm{C} 23 \mathrm{O}$ from step 1 was loaded on to the column and a first linear gradient to $10 \%$ buffer $\mathrm{D}$ (buffer $\mathrm{C}$ containing $1 \mathrm{M} \mathrm{Na}_{2} \mathrm{SO}_{4}$ ) was applied over $10 \mathrm{~min}$. This was followed by a second linear gradient to $20 \%$ buffer D over $30 \mathrm{~min}$, and a step gradient to $100 \%$ buffer D for $10 \mathrm{~min}$. A step gradient to $100 \%$ buffer $C$ for $15 \mathrm{~min}$ regenerated the initial conditions. Fractions were tested for $\mathrm{C} 23 \mathrm{O}$ activity. Active fractions were pooled and used immediately and without further treatment in step (3).

C23O-I was examined in a modified step (2) in which all $50 \mathrm{mM}$ buffers were replaced by $20 \mathrm{mM}$ buffers. BS(TS)DOS from step (1) was separated under routine conditions, where no single fraction catalysed BS (TS)-dependent oxygen uptake, but combinations of fractions were active.

Step 3. A gel-filtration column (Superose-6; $10 \times 300 \mathrm{~mm}$ ) was equilibrated at room temperature with buffer $\mathrm{C}$ containing $150 \mathrm{mM} \mathrm{Na}_{2} \mathrm{SO}_{4}$ at $0.6 \mathrm{ml} \mathrm{min}{ }^{-1}$, and $1 \mathrm{ml}$ fractions were collected. Preparative separations were done with $2 \mathrm{ml}$ portions

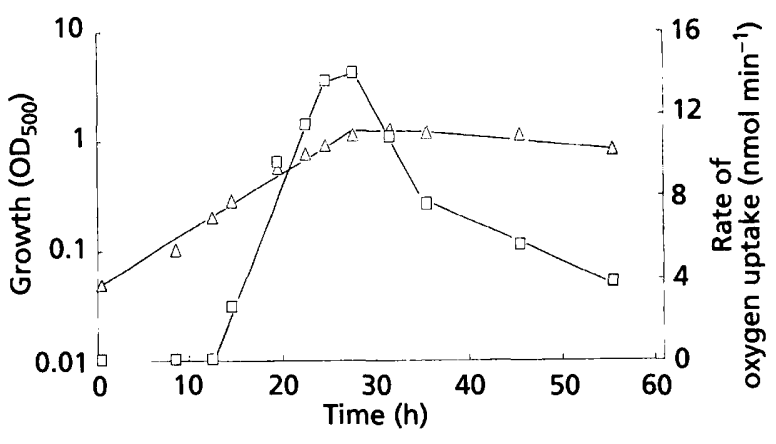

Fig. 2. Growth of Alcaligenes sp. strain $0-1$ in BS-salts medium and the BS-dependent oxygen uptake of whole cells during growth. The culture was inoculated with exponentially growing cells as indicated in Methods. Samples were taken at intervals to assay optical density, to determine the concentrations of protein and substrate and to measure the oxygen uptake of whole cells. The samples $(1.0 \mathrm{ml})$ for oxygen uptake were centrifuged $\left(10000 \mathrm{~g}, 1 \mathrm{~min}\right.$, about $\left.20^{\circ} \mathrm{C}\right)$ and the supernatant fluid was discarded; the cells were resuspended immediately in $50 \mathrm{mM} \mathrm{Tris} / \mathrm{HCl}$ buffer, $\mathrm{pH} 7.5$ and washed $(10000 \mathrm{~g}, 1 \mathrm{~min}$, about $20^{\circ} \mathrm{C}$ ). The cells were suspended in fresh Tris/ $\mathrm{HCl}$ buffer and examined immediately for BS-dependent oxygen uptake. $\triangle, \mathrm{OD}_{500} ; \square$, oxygen uptake rate.

applied to the column. Values for native $M_{\mathbf{r}}$ were obtained by chromatographing $50 \mu \mathrm{l}$ portions and interpolating data into standard curves generated by chromatographing $50 \mu \mathrm{l}$ of standard proteins.

\section{RESULTS}

\section{Growth of Alcaligenes sp. strain 0-1 in BS- and TS- salts medium}

Strain O-1 grew in BS-salts medium $\left(\mu=0 \cdot 16 \mathrm{~h}^{-1}\right.$; Fig. 2) and growth was concomitant with substrate utilization (not shown). The BS-depenent uptake of oxygen by washed cells from the culture, an assay for the putative BSDOS, was initially undetectable, increased to a maxi-

Table 1. Comparison of oxygen uptake rates with various sulphonate substrates in differently grown cells of Alcaligenes sp. strain 0-1 and in extracts from these cells

\begin{tabular}{|c|c|c|c|c|c|c|c|c|}
\hline \multirow[t]{3}{*}{$\begin{array}{l}\text { Growth } \\
\text { substrate }\end{array}$} & \multicolumn{6}{|c|}{$\begin{array}{c}\text { Ratios of oxygen uptake rates with individual substrates } \\
\text { under different conditions }\end{array}$} & \multicolumn{2}{|c|}{$\begin{array}{c}\text { Oxygen uptake } \\
\text { rate with BS } \\
{\left[\text { mkat }(\text { kg protein })^{-1}\right]}\end{array}$} \\
\hline & \multicolumn{2}{|c|}{ BS:2AS } & \multicolumn{2}{|c|}{ BS: TS } & \multicolumn{2}{|c|}{ TS:2AS } & \multirow{2}{*}{ Cells } & \multirow{2}{*}{ Extracts } \\
\hline & Cells & Extracts & Cells & Extracts & Cells & Extracts & & \\
\hline \multirow[t]{2}{*}{$2 \mathrm{AS}$} & 0.4 & & $1 \cdot 2$ & & 0.5 & & 1.8 & \\
\hline & & 0.9 & & $1 \cdot 1$ & & 0.7 & & $0 \cdot 07$ \\
\hline \multirow[t]{2}{*}{ BS } & $2 \cdot 6$ & & $1 \cdot 9$ & & $1 \cdot 4$ & & $2 \cdot 9$ & \\
\hline & & $2 \cdot 0$ & & $1 \cdot 2$ & & 1.6 & & 0.07 \\
\hline \multirow[t]{2}{*}{ TS } & $2 \cdot 9$ & & $1 \cdot 8$ & & 1.6 & & $3 \cdot 5$ & \\
\hline & & $2 \cdot 9$ & & 1.4 & & $2 \cdot 0$ & & $0 \cdot 17$ \\
\hline
\end{tabular}


Table 2. Stoichiometry of oxygen uptake with different substrates by whole cells of Alcaligenes sp. strain 0-1 grown with one of three sulphonated substrates

The values represent the mean of three determinations. No assay differed by more than $10 \%$ from the data shown.

\begin{tabular}{|c|c|c|c|c|c|c|}
\hline \multirow[t]{2}{*}{$\begin{array}{l}\text { Growth } \\
\text { substrate }\end{array}$} & \multicolumn{6}{|c|}{$\begin{array}{l}\text { Stoichiometry of oxygen consumption with different substrates } \\
\qquad\left[\mathrm{mol} \mathrm{O}_{2}(\mathrm{~mol} \text { substrate })^{-1}\right]\end{array}$} \\
\hline & $2 \mathrm{AS}$ & BS & TS & $3 \mathrm{SC}$ & Catechol & $\begin{array}{l}\text { 4-Methyl- } \\
\text { catechol }\end{array}$ \\
\hline $2 A S$ & $2 \cdot 0$ & $2 \cdot 0$ & $2 \cdot 1$ & $1 \cdot 0$ & $1 \cdot 0$ & 0.9 \\
\hline BS & $1 \cdot 0$ & $2 \cdot 0$ & $2 \cdot 1$ & $<0.1$ & $1 \cdot 0$ & 0.9 \\
\hline TS & $\mathrm{NA}^{*}$ & $2 \cdot 0$ & $2 \cdot 0$ & $<0.1$ & $1 \cdot 0$ & $1 \cdot 0$ \\
\hline
\end{tabular}

* NA, No assay; the TS-grown cells had a high rate of endogenous respiration and no accurate data could be obtained for the poor substrate $2 \mathrm{AS}$.

mum at or slightly prior to exhaustion of the carbon source (28-30 h), and then dropped markedly and reached zero (about $60 \mathrm{~h}$ ). Cells were harvested at an $\mathrm{OD}_{500}$ of $1 \cdot 1$. Growth in TS-salts medium was analogous, with marked loss of the putative TSDOS in the stationary phase $(\mu=$ $0.08 \mathrm{~h}^{-1}$; cells harvested at $\mathrm{OD}_{500}$ of $1 \cdot 2$ ) (not shown).

This behaviour of the putative dioxygenase system(s) is analogous to the behaviour of 2ASDOS in 2AS-grown cells (Thurnheer et al., 1986, 1990; Jahnke et al., 1993; Junker et al., 1994). Loss of oxygenase activity in the stationary phase is well known (e.g. Moodie et al., 1990; Bünz \& Cook, 1993).

\section{Oxygen uptake by whole cells and cell extracts}

Oxygen uptake by optimally grown whole cells from 2AS-, BS-, TS- or succinate-salts medium was examined with the substrates 2 AS, BS, TS and succinate. Succinategrown cells showed significant oxygen uptake with succinate, but they showed no oxygen uptake with 2AS, BS or TS. The enzymes required for degradation of the arylsulphonates are thus inducible, in agreement with earlier data (Thurnheer et al., 1986).

2AS-, BS- and TS-grown cells showed two patterns of oxygen uptake (Table 1). 2AS-grown cells had a high uptake rate with $2 \mathrm{AS}$ compared with BS and TS (ratio BS: 2 AS of 0.4 ). In both BS- and TS-grown cells, BS led to the highest uptake rate and 2AS the lowest rate of uptake (ratio BS:2AS of 2.6 to 2.9 ). The ratios of different activities (Table 1) indicate that BS- and TS-cells could have one enzyme complement, probably expressed at different levels in BS- and TS-cells (Table 1, right-hand column), whereas 2AS-cells have a different set of enzymes. The oxygen uptake rates by cell extracts displayed analogous behaviour to whole cells, which supports the conclusion from experiments with whole cells (Table 1).
The stoichiometry of oxygen uptake for different substrates also showed differences between 2AS-grown cells, on the one hand, and BS- and TS-grown cells, on the other (Table 2). Whereas BS or TS caused the utilization of $2 \mathrm{~mol} \mathrm{O}_{2}$ (mol sulphonate) $)^{-1}$, and $1 \mathrm{~mol} \mathrm{O}_{2}$ (mol catechol or 4-methylcatechol $)^{-1}$ under all conditions, 2AS caused the uptake of $2 \mathrm{~mol} \mathrm{O}_{2}(\mathrm{~mol} 2 \mathrm{AS})^{-1}$ solely in 2AS-grown cells. BS- or TS-grown cells catalysed the consumption of only $1 \mathrm{~mol} \mathrm{O}_{2}(\mathrm{~mol} 2 \mathrm{AS})^{-1}$ (where measurable) and the corresponding catechol, 3SC, was not oxygenated. Similar data were obtained with crude extracts (not shown).

We thus hypothesized that there are two NADHdependent dioxygenases, 2ASDOS and BSDOS, and that the latter is identical with TSDOS. It was unclear whether both may be present under some conditions. There must also be two meta cleavage enzymes, one of which does not desulphonate 3SC.

\section{Dioxygenases in strain 0-1 grown in 2AS-, BS- or TS-salts medium}

Extract from cells grown optimally in 2AS-, BS- or TSsalts medium was applied to the DEAE anion-exchange column and the proteins were separated under identical conditions. Two patterns were observed. In extracts of 2AS-grown cells, the 2ASDOS was separated into two fractions, iv (red in colour) and $\mathrm{v}$ (yellow in colour) in Fig. 3(c), and one catechol 2,3-dioxygenase, 3-sulphocatechol-2,3-dioxygenase (3SC23O, vi in Fig. 3(c)) was detected. No other oxygenase was observed. The fractions of 2ASDOS were attributed to a reductase (fraction v), which reduced cytochrome $c$ and dichlorophenol indophenol, and to an oxygenase (fraction iv) which was active only in the presence of the reductase. The separations of proteins from BS- and TS-grown cells gave chromatograms which were apparently identical with one another (Fig. 3a, b). The putative BSDOS (TSDOS) eluted in one peak (iii in Fig. 3a, b) with different 

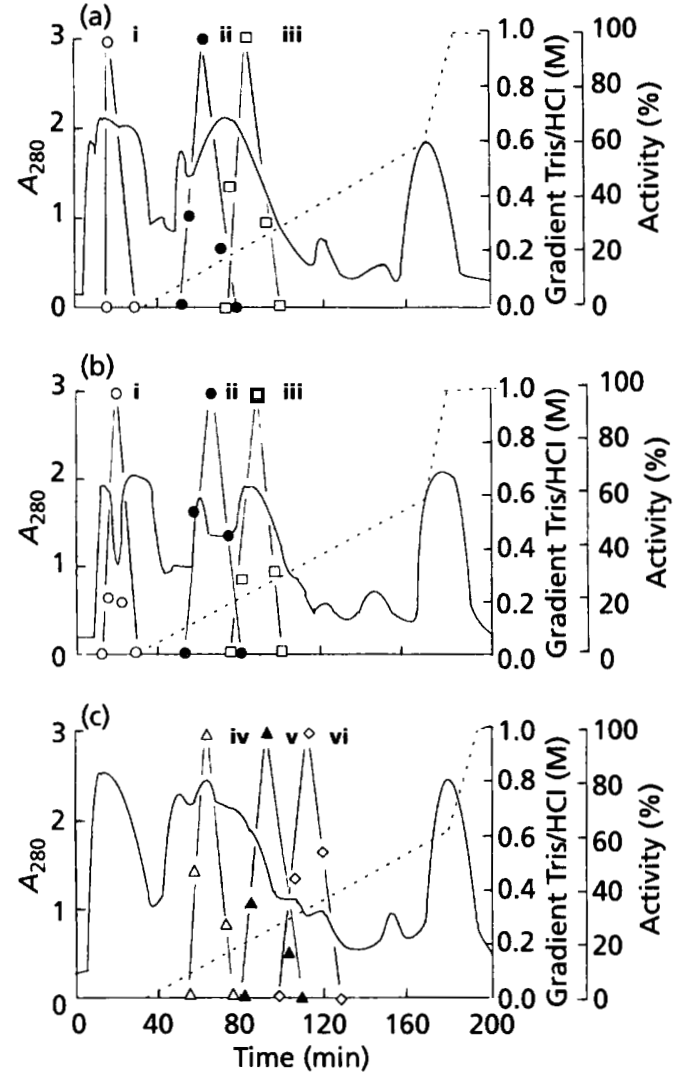

Fig. 3. Separation on an anion exchanger of the enzymes catalysing the first two reactions in the degradation of BS, TS or 2AS by extracts of Alcaligenes sp. strain 0-1 from BS-, TS- or 2AS-medium. Extract from BS-grown cells (a), TS-grown cells (b) or 2AS-grown cells (c) of Alcaligenes sp. strain 0-1 was loaded on to a DEAE-Sepharose column and separated as detailed in Methods. The elution of protein $\left(A_{280},-\right)$, the gradient of Tris buffer (--), C230 activities $(0,0)$, BS(TS)DOS ( $\square$ ), 2ASDOS reductase $(\triangle), 2$ ASDOS oxygenase $(\boldsymbol{\Delta})$ and $3 S C 230(\diamond)$ are shown.

chromatographic properties (elution at $200 \mathrm{mM}$ Tris) from the components of 2ASDOS (reductase eluted at $250 \mathrm{mM}$ Tris, oxygenase at $165 \mathrm{mM}$ Tris). BSDOS was confirmed to be a multi-component system on a subsequent and more selective anion-exchange column (Mono Q; not shown). Two peaks of activity for catechol 2,3-dioxygenase $(\mathrm{C} 23 \mathrm{O}$ ) were located ( $\mathrm{i}$ and ii in Fig. $3 \mathrm{a}, \mathrm{b})$, neither of which corresponded to $3 \mathrm{SC} 23 \mathrm{O}$. The major activity, peak ii ( $>90 \%$ of the total ; termed C23OIII) eluted near the middle of the gradient, whereas peak i was resolved into one (TS-cells; C23O-II) or two (BScells, C23O-I and C23O-II) minor activities by subsequent chromatography (Table 3).

\section{The multi-component dioxygenases}

The separated 2ASDOS oxygenated the three tested substrates, $2 \mathrm{AS}, \mathrm{BS}$ and TS, and one product was observed in each case (3SC, catechol and 4-methylcatechol, respectively). These products were identified by co-chromatography (HPLC) with the appropriate auth-

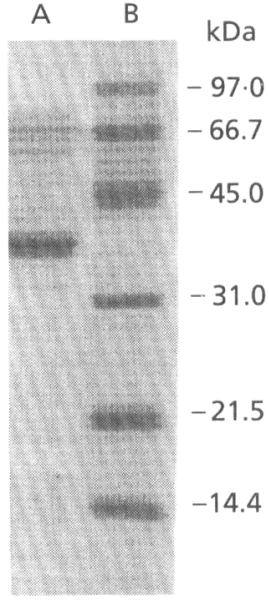

Fig. 4. SDS-PAGE of purified 3SC230. Proteins were stained with Coomassie blue in $12 \%$ gels. Track A, $35 C 230$ ( $3 \mu \mathrm{g}$ protein); track B, standard protein markers.

entic material and by identity of the appropriate UV spectra with the spectrum of the standard (Junker $e$ t al., 1994; see Thurnheer $e t a l ., 1990$ for representative spectral data). The enzyme system thus has a wide substrate range and is apparently capable of causing the removal of either the amino substituent or a sole sulphono substituent on the ring.

The multi-component oxygenase from BS- or TS-grown cells could also oxygenate the three substrates tested. The product from BS (TS) was catechol (4-methylcatechol), which was identified by co-chromatography and UV spectra (see previous paragraph). In the case of $2 \mathrm{AS}$, two products were detected in low yield. One product was 3SC, identified by co-chromatography and by UV spectra. The other product was presumably the unstable 3aminocatechol, which we deduced from its chromatographic behaviour (retention time about $4.8 \mathrm{~min}$ ) and UV spectrum $\left(\lambda_{\min } 243 \mathrm{~nm} ; \lambda_{\max } 272 \mathrm{~nm}\right)$ because these compare with data we generated earlier ( $4.6 \mathrm{~min}: 243 \mathrm{~nm}$; $272 \mathrm{~nm}$ : Thurnheer et al., 1990). We have thus the same enzyme system (BSDOS) in both BS- and TS-grown cells. BSDOS also appears to have a wide substrate range and to catalyse both desulphonation and deamination.

\section{The purification of $35 \mathrm{C} 230$ and the separation of other meta cleavage enzymes}

$3 \mathrm{SC} 23 \mathrm{O}$ could be purified to about $90 \%$ purity in a threestep procedure (Fig. 4, Table 4). The enzyme would appear to be a monomer (Table 3) with the following $\mathrm{N}$ terminal amino acid sequence: Met-Gln-Val-Arg-Leu-IleLeu-X-Ser-His-Ser-Pro-Leu-Met-Leu-Lys-Glu-Met-ProGlu-Thr-Leu-Pro-. This sequence was not detected in databases (GenEMBL and SwissPro). The enzyme is very labile and shortly after the purification the activity is permanently lost. 
Table 3. Properties of the four catechol meta cleavage enzymes observed under the experimental conditions used

\begin{tabular}{|c|c|c|c|c|c|c|c|c|c|}
\hline \multirow[t]{3}{*}{ Catechol 2,3-dioxygenase* } & \multirow{2}{*}{\multicolumn{2}{|c|}{$\begin{array}{c}\text { Elution from anion } \\
\text { exchanger } \dagger\end{array}$}} & \multicolumn{2}{|c|}{$M_{\mathrm{r}}$ values $\ddagger$} & \multicolumn{5}{|c|}{ Substrate spectrum $\S$} \\
\hline & & & \multirow{2}{*}{ Native } & \multirow{2}{*}{ Denatured } & \multirow{2}{*}{ CAT } & \multirow{2}{*}{$3 \mathrm{SC}$} & \multirow{2}{*}{$3 \mathrm{MC}$} & \multirow{2}{*}{$4 \mathrm{MC}$} & \multirow{2}{*}{ 23B } \\
\hline & $\begin{array}{c}\text { DEAE } \\
\text { (Tris/HCl) }\end{array}$ & $\begin{array}{c}\text { Mono Q } \\
\left(\text { Tris } / \mathbf{H}_{2} \mathbf{S O}_{4}\right)\end{array}$ & & & & & & & \\
\hline \multicolumn{10}{|l|}{ From 2AS-grown cells } \\
\hline $3 \mathrm{SC} 23 \mathrm{O}(100 \%)$ & $320 \mathrm{mM}$ & $130 \mathrm{mM}$ & 46000 & 42000 & 100 & 71 & 92 & 92 & 4 \\
\hline \multicolumn{10}{|l|}{ From BS-grown cells } \\
\hline $\mathrm{C} 23 \mathrm{O}-\mathrm{I}(1 \%)$ & None & $20 \mathrm{mM}$ & ND & 39000 & 100 & 0 & 94 & 44 & 10 \\
\hline C23O-II $(<1 \%)$ & None & $100 \mathrm{mM}$ & ND & $\mathrm{ND}$ & & & & & \\
\hline C23O-III $(98 \%)$ & $140 \mathrm{mM}$ & $110 \mathrm{mM}$ & 79000 & 37000 & 100 & 0 & 133 & 57 & $2 \cdot 3$ \\
\hline \multicolumn{10}{|l|}{ From TS-grown cells } \\
\hline C23O-II (7\%) & None & $100 \mathrm{mM}$ & 87000 & 38000 & 100 & 0 & 115 & 18 & 0 \\
\hline C23O-III (93\%) & $140 \mathrm{mM}$ & $110 \mathrm{mM}$ & 79000 & 37000 & 100 & 0 & 133 & 55 & $2 \cdot 5$ \\
\hline
\end{tabular}

ND, Not determined.

* Numbers in parentheses are percentages of the total activity of meta-cleavage enzyme present, measured with catechol as substrate.

†The values refer to the concentration of the gradient at which the peak-maximum eluted.

$\ddagger$ The values were obtained by gel-filtration chromatography (native) and SDS-PAGE (denatured).

\Abbreviations: CAT, catechol; 3SC, 3-sulphocatechol; 3MC, 3-methylcatechol; 4MC, 4-methylcatechol; 23B, 2,3-dihydroxybenzoate. The numbers refer to the relative specific activities of the enzyme preparations with 100 representing the specific activity with catechol as a substrate.

Table 4. Purification of 3-sulphocatechol 2,3-dioxygenase

The table is representative of six purifications.

\begin{tabular}{|c|c|c|c|c|c|c|}
\hline Purification step & $\begin{array}{l}\text { Vol. } \\
(\mathrm{ml})\end{array}$ & $\begin{array}{c}\text { Total } \\
\text { activity } \\
\text { ( } \mu \text { kat) }\end{array}$ & $\begin{array}{c}\text { Protein } \\
\left(\mathrm{mg} \mathrm{ml}^{-1}\right)\end{array}$ & $\begin{array}{c}\text { Specific } \\
\text { activity } \\
{[\mathrm{mkat}} \\
\left.(\mathrm{kg} \text { protein })^{-1}\right]\end{array}$ & $\begin{array}{l}\text { Yield } \\
(\%)\end{array}$ & $\begin{array}{c}\text { Purification } \\
\text { (-fold) }\end{array}$ \\
\hline Crude extract & 25 & $2 \cdot 3$ & 17 & $5 \cdot 5$ & 100 & 1 \\
\hline DEAF & 47 & 1.9 & $1 \cdot 8$ & 22 & 83 & $4 \cdot 1$ \\
\hline Mono $Q$ & $20^{*}$ & $1 \cdot 7$ & 0.94 & 92 & 75 & 17 \\
\hline Superose-6 & $20^{*}$ & $1 \cdot 0$ & 0.60 & 87 & 45 & 16 \\
\hline
\end{tabular}

* Multiple portions of the preceding pool were chromatographed.

$3 \mathrm{SC} 23 \mathrm{O}$ was the only catechol dioxygenase detected in 2AS-grown cells. It was not detectable in extracts of BSor TS-grown cells (Fig. 3). Extracts of BS- or TS-grown cells, in contrast, contained multiple $\mathrm{C} 23 \mathrm{Os}$, none of which oxygenated 3SC (Fig. 3, Table 3). The major portion of the activity in each case was termed C23O-III, which we presume to be identical in BS- and TS-cells, because the chromatographic behaviour on two columns, the $M_{\mathrm{r}}$-values for native and denatured protein, and the substrate ranges were found to be identical.

The minor portions of $\mathrm{C} 23 \mathrm{O}$ were termed $\mathrm{C} 23 \mathrm{O}-\mathrm{I}$ and C23O-II. None of the four catechol dioxygenases has the same pattern of substrate turnover (Table 3). C23O-I was detected in extracts of BS-grown cells only. C23O-II probably occurs in both BS- and TS-grown cells, but there was insufficient activity in extracts of BS-grown cells to confirm this. The level of activity of C23O-II in TSgrown cells leads us to believe that the enzyme is involved in the degradation of substituted catechols in another pathway and that it has been induced by traces of, e.g. methylcatechol or even catechol.

\section{DISCUSSION}

$2 \mathrm{ASDOS}$ and $3 \mathrm{SC} 23 \mathrm{O}$ were not synthesized by Alcaligenes sp. strain O-1 in the absence of $2 \mathrm{AS}$; the enzymes were induced specifically in 2AS-salts medium. Similarly, 
BSDOS and C23O-III were induced specifically in BS- (or TS-) salts medium. The regulation of enzyme synthesis is thus highly specific. Given that other multi-component oxygenases and the corresponding ring cleavage enzymes are often encoded in operons (Harayama et al., 1992), we hypothesize that two independent operons encoding desulphonative pathways may be present in Alcaligenes sp. strain O-1.

In contrast to the high specificity of induction of these two putative operons, the enzymes they encode displayed a lower specificity. It was this phenomenon, indeed, which led us to examine the enzymes (see Introduction). It is now clear that 2ASDOS is a completely separate entity from BSDOS. The oxygenase components of the two systems elute from the DEAE column at $165 \mathrm{mM}$ Tris and $200 \mathrm{mM}$ Tris, respectively (Fig. 3), and it is the oxygenase component of the enzyme system that interacts with the substrate which is oxygenated. We thus see from Table 1 that BSDOS in crude extract of BS-grown cells oxygenates BS twice as fast as 2AS. 2ASDOS in crude extract oxygenates $\mathrm{BS}$ and $\mathrm{AS}$ at similar rates. The apparent specific activity of 2ASDOS is apparently too low (Table 1) to account for the oxygen uptake rate by whole cells, but the non-linear response of this multicomponent system to protein concentration masks a higher real specific activity (Thurnheer et al., 1990; cf. Locher et al., 1991). Just as 2ASDOS oxygenates BS (or TS) to catechol (or 4-methylcatechol) with unit stoichiometry (Thurnheer et al., 1990), BSDOS oxygenates BS (or TS) to catechol (or 4-methylcatechol) with unit stoichiometry (this paper and F. Junker, unpublished data). The reductases from $2 A S D O S$ and BSDOS also elute reproducibly at different positions on the gradient (250 and $200 \mathrm{mM}$, respectively). The main meta cleavage enzymes (3SC23O and C23O-III; Fig. 3, Table 3) in the two putative operons are also obviously different.

Whereas 2ASDOS or BSDOS catalyses the first metabolic reaction in the degradation of arylsulphonates by strain O-1, the first specific interaction of, e.g. 2AS with the cell is transport (Thurnheer et al., 1990; cf. Locher et al., 1993). We have no indication of how many transport systems are present or how these systems are regulated.

$3 \mathrm{SC} 23 \mathrm{O}$ catalyses the standard $\mathrm{C} 23 \mathrm{O}$ reaction (Table 3 ; Junker et al., 1994) and is inhibited by 3-chlorocatechol (Junker et al., 1994), and would therefore appear to be a normal meta cleavage enzyme (EC 1.13.11.2). Most $\mathrm{C} 23 \mathrm{Os}$, however, do not seem to oxygenate 3SC (Table 3). If 3-chlorocatechol inhibits a $\mathrm{C} 23 \mathrm{O}$ by oxygenation to the acyl chloride which derivatizes and permanently inhibits the enzyme (Bartels et al., 1984), why does the highly unstable acyl sulphonate (sulphonoaldehyde) not display the same inhibitory effect? Junker et al. (1994) produced mg-amounts of product from 3SC with $3 \mathrm{SC} 23 \mathrm{O}$, whereas $\mu \mathrm{g}$-amounts of 3-chlorocatechol are inhibitory. Indeed, $3 \mathrm{SC} 23 \mathrm{O}$ in crude extract, though temporarily inhibited by 3-fluorocatechol, recovers from the inhibition (A. M. Cook, unpublished). This information raises the question of the extent of inhibition of a
C23O by derivatization (Bartels et al., 1984) and by chelation of the iron cofactor (Klecka \& Gibson, 1981). We wonder whether the acyl sulphonate is stable in the active site, and is only unstable in solution. $3 \mathrm{SC} 23 \mathrm{O}$ is also unusual amongst $\mathrm{C} 23 \mathrm{Os}$ in being monomeric (Table 3). We know of only one other monomeric C23O, that in Sphingomonas sp. strain RW1 (Happe et al., 1993), others being homomultimeric (Harayama et al., 1992; Kataeva \& Golovleva, 1990). We plan to clone the gene encoding this seemingly unusual enzyme and, if appropriate from the sequence, attribute the enzyme to one of the known families of meta cleavage enzymes (cf. Harayama et al., 1992).

The instability of $3 \mathrm{SC} 23 \mathrm{O}$ prevented extensive studies of its properties. Lipscomb \& Orville (1992) have several suggestions for stabilizing these enzymes, and Happe $e$ al . (1993) achieved satisfactory stability of a C23O by purifying under anaerobic conditions. Despite the poor stability of $3 \mathrm{SC} 23 \mathrm{O}$, the specific activity observed in crude extracts with catechol as substrate $[5.5 \mathrm{mkat}(\mathrm{kg}$ protein $)^{-1}$; Table 4), which represents about 3.9 mkat (kg protein) $)^{-1}$ with $3 \mathrm{SC}$ (Table 3), is sufficient to explain the flux through growing cells, which we calculate to be $0.8 \mathrm{mkat}$ ( $\mathrm{kg}$ protein) ${ }^{-1}$ from the growth rate and the growth yield (cf. Junker et al., 1994). In agreement with this calculation, whole cells in suspension display oxygen uptake rates of this order of magnitude (Table 1).

A common factor amongst 3SC23O (EC 1.13.11.-), 2ASDOS and BSDOS (both presumably EC 1.14.12.-) is the apparently spontaneous elimination reaction (loss of the anion sulphite, ammonia and sulphite, respectively) induced by oxygenation in the named reaction (cf. Junker et al., 1994). The spontaneous reaction arises from the unstable formal intermediate generated by oxygenation. This intermediate is a cis-diol, one of whose carbon atoms is also bound to a heteroatom which is simultaneously a good leaving group. Spontaneous loss of the good leaving group is simultaneously a rearomatization to the catechol (Locher et al., 1991; Junker et al., 1994). We have previously discussed the possibility that the spontaneity may be only apparent, because we do not know to what extent specific catalysis or spontaneous decay cause loss of anion (Bünz \& Cook, 1993; Junker et al., 1994). The data presented here argue more for spontaneity. The 2ASDOS fractions can cause not only deamination but also desulphonation, and the BSDOS fractions can cause not only desulphonation but also possibly deamination. The question can only be better resolved when pure enzymes become available.

Strain O-1 is not the only organism to catalyse two desulphonations. Wittich et al. (1988) describe a Moraxella sp. which obviously contains both a dioxygenase and a putative monooxygenase involved in desulphonation, though these activities do not seem to be stable in cell-free extracts. Strain O-1 thus remains the only organism where several desulphonations can be examined at the enzymic level. 
With some notable exceptions, multiple-component (di)oxygenases have seldom been examined at the biochemical level (Mason \& Cammack, 1992). One reason for this is probably the oxygen-sensitive nature of the enzymic components. Another is the sometimes low yield of enzyme on disruption of cells (Table 1). Yet another is probably the large amount of enzyme required in assays ( $2 \mathrm{mg} \mathrm{ml}^{-1}$ in this work; cf. Thurnher et al., 1990; Geary et al., 1990). We presume that another difficulty is harvesting the cells at the correct time. Fig. 2 shows the relatively sharp spike in specific activity of BSDOS (whether from BS- or TS-grown cells). The same behaviour is seen with 2ASDOS (Junker et al., 1994; cf. Jahnke et al., 1993) where unpublished data show the optimal timing to be in a $2 \mathrm{~h}$ window just before the end of growth, similar to data from Bünz \& Cook (1993). Moodie $e t$ al. (1990) have localized the effect in benzoate dioxygenase to loss of the reductase.

\section{ACKNOWLEDGEMENTS}

We are grateful to M. Kertesz for constructive criticism and advice. F. J. was supported by the Swiss Federal Institute of Technology, Zürich, and by the Deutscher Akademischer Austauschdienst, in an exchange programme.

\section{REFERENCES}

Bartels, I., Knackmuss, H.-J. \& Reineke, W. (1984). Suicide inactivation of catechol 2,3-dioxygenase from Pseudomonas putida mt-2 by 3-halocatechols. Appl Environ Microbiol 47, 500-505.

Batie, C. J., Ballou, D. P. \& Correll, C. C. (1992). Phthalate dioxygenase reductase and related flavin-iron-sulfur containing electron transferases. In Chemistry and Biochemistry of Flavoenzymes, vol. 3, pp. 543-556. Edited by F. Müller. Boca Raton: CRC Press.

Bayly, R. C. \& Barbour, M. G. (1984). The degradation of aromatic compounds by the meta and gentisate pathways. In Microbial Degradation of Organic Compounds, pp. 253-294. Edited by D. T. Gibson. New York: Marcel Dekker.

Bird, J. A. \& Cain, R. B. (1974). Microbial degradation of alkylbenzenesulphonates: metabolism of homologues of short alkylchain length by an Alcaligenes sp. Biochem J 140, 121-134.

Bradford, M. (1976). A rapid and sensitive method for the quantification of microgram quantities of protein utilizing the principle of protein-dye binding. Anal Biochem 72, 248--254.

Bünz, P. \& Cook, A. M. (1993). Dibenzofuran 4,4a-dioxygenase from Sphingomonas sp. strain RW1: angular dioxygenation by a three-component enzyme system. J Bacteriol 175, 6467-6475.

Cook, A. M. \& Leisinger, T. (1991). Desulfonation of aromatic compounds. In Environmental Biotechnology, vol. 1, pp. 115-122. Edited by H. Verachtert \& W. Verstraete. Antwerp: Koninklijke Vlaamse Ingenieursveniging.

Correll, C. C., Batie, C. J., Ballou, D. P. \& Ludwig, M. L. (1992). Phthalate dioxygenase reductase: a modular structure for electron transfer from pyridine nucleotides to $[2 \mathrm{Fe}-2 \mathrm{~S}]$. Science 258, 1604 1610.

Engesser, K. H., Strubel, V., Christoglou, K., Fischer, P. \& Rast, H. G. (1989). Dioxygenolytic cleavage of aryl ether bonds: 1,10dihydro-1,10-dihydroxyfluoren-9-one, a novel arene dihydrodiol as evidence for angular dioxygenation of dibenzofuran. FEMS Microbiol Lett 65, 205-210.
Feigel, B. \& Knackmuss, H.-J. (1993). Syntrophic interactions during degradation of 4-aminobenzenesulfonic acid by a two species bacterial culture. Arch Microbiol 159, 124-130.

Geary, P. J., Mason, J. R. \& Joannou, C. L. (1990). Benzene dioxygenase from Pseudomonas putida ML2 (NCIB 12190). Methods Enzymol 188, 52-60.

Grossenbacher, H., Thurnheer, T., Zürrer, D. \& Cook, A. M. (1986). Determination of sulfonated azo dyestuffs and their bacterial metabolites by high pressure liquid chromatography. J Chromatogr 360, 219-223.

Happe, B., Eltis, L. D., Poth, H., Hedderich, R. \& Timmis, K. N. (1993). Characterization of 2,2',3-trihydroxybiphenyl dioxygenase, an extradiol dioxygenase from the dibenzofuran- and dibenzo- $p$ dioxin-degrading bacterium Sphingomonas sp. strain RW1. J Bacteriol $175,7313-7320$

Harayama, S., Kok, M. \& Neidle, E. L. (1992). Functional and evolutionary relationships among diverse oxygenases. Annu Rev Microbiol 46, 565-601.

Jahnke, M., El-Banna, T., Klintworth, R. \& Auling, G. (1990). Mineralization of orthanilic acid is a plasmid-associated trait in Alcaligenes sp. O-1. J Gen Microbiol 136, 2241-2249.

Jahnke, M., Lehmann, F., Schoebel, A. \& Auling, G. (1993). Transposition of the TOL catabolic genes ( $\operatorname{Tn} 4651$ ) into the degradative plasmid pSAH of Alcaligenes sp. O-1 ensures simultaneous mineralization of sulpho- and methyl-substituted aromatics. J Gen Microbiol 139, 1959-1966.

Junker, F., Field, J. A., Bangerter, F., Ramsteiner, K., Kohler, H.-P., Joannou, C. L., Mason, J. R., Leisinger, T. \& Cook, A. M. (1994). Dioxygenation and spontaneous deamination of 2-aminobenzenesulphonic acid in Alcaligenes sp. strain O-1 with subsequent meta ring cleavage and spontaneous desulphonation to 2-hydroxymuconic acid. Biochem J 300, 429-436.

Kataeva, I. A. \& Golovleva, L. A. (1990). Catechol 2,3-dioxygenase from Pseudomonas aeruginosa 2x. Methods Enzymol 188, 115-121.

Kennedy, S. I. T. \& Fewson, C. A. (1968). Enzymes of the mandelate pathway in bacterium N.C.I.B. 8250. Biochem J 107, 497-506.

Klecka, G. M. \& Gibson, D. T. (1981). Inhibition of catechol 2,3dioxygenase from Pseudomonas putida by 3-chlorocatechol. Appl Environ Microbiol 41, 1159-1165.

Laemmli, U. K. (1970). Cleavage of structural proteins during the assembly of the head of bacteriophage T4. Nature 227, 680-685.

Lipscomb, J. D. \& Orville, A. M. (1992). Mechanistic aspects of dihydroxybenzoate dioxygenases. Metal Ions Biol Syst 28, 243-298.

Locher, H. H., Leisinger, T. \& Cook, A. M. (1989). Degradation of $p$ toluenesulphonic acid via sidechain oxidation, desulphonation and meta ring cleavage in Pseudomonas (Comamonas) testosteroni T-2. J Gen Microbiol 135, 1969-1978.

Locher, H. H., Leisinger, T. \& Cook, A. M. (1991). Sulphobenzoate 3,4-dioxygenase: purification and properties of a desulphonative two-component enzyme system from Comamonas testosteroni. Biochem J 274, 833-842.

Locher, H. H., Poolman, B., Cook, A. M. \& Konings, W. N. (1993). Uptake of 4-toluenesulfonate by Comamonas testosteroni T-2. J Bacteriol 175, 1075-1080.

Mason, J. R. \& Cammack, R. (1992). The electron-transport proteins of hydroxylating bacterial dioxygenases. Annu Rev Microbiol 46, $277-305$.

Moodie, F. D. L., Woodland, M. P. \& Mason, J. R. (1990). The reductase component of the chromosomally encoded benzoate dioxygenase from Pseudomonas putida C-1 is immunologically 
homologous with a product of the plasmid encoded $x y / \mathrm{D}$ gene (toluate dioxygenase) from Pseudomonas putida mt-2. FEMS Microbiol Lett 71, 163-168.

Thurnheer, T., Köhler, T., Cook, A. M. \& Leisinger, T. (1986). Orthanilic acid and analogues as carbon sources for bacteria: growth physiology and enzymic desulphonation. $J$ Gen Microbiol 132, 1215-1220.

Thurnheer, T., Zürrer, D., Höglinger, O., Leisinger, T. \& Cook, A. M. (1990). Initial steps in the degradation of benzene sulfonic acid, 4-toluene sulfonic acid, and orthanilic acid in Alcaligenes sp. strain O-1. Biodegradation 1, 55-64.

Webb, E. C. (1992). Enzyme Nomenclature 1992. San Diego: Academic Press.

Whitman, C. P., Aird, B. A., Gillespie, W. R. \& Stolowich, N. J.
(1991). Chemical and enzymatic ketonization of 2-hydroxymuconate, a conjugated enol. $J$ Am Chem Soc 113, 3154-3162.

Wittich, R. M., Rast, H. G. \& Knackmuss, H.-J. (1988). Degradation of naphthalene-2,6- and naphthalene-1,6-disulfonic acid by a Moraxella sp. Appl Environ Microbiol 54, 1842-1847.

Zamanian, M. \& Mason, J. R. (1987). Benzene dioxygenase in Pseudomonas putida: subunit composition and immuno-cross-reactivity with other aromatic dioxygenases. Biochem J 244, 611-616.

Zürrer, D., Cook, A. M. \& Leisinger, T. (1987). Microbial desufonation of substituted naphthalenesulfonic acids and benzenesulfonic acids. Appl Environ Microbiol 53, 1459-1463.

Received 26 August 1993; revised 4 January 1994; accepted 1 February 1994. 